\title{
The Malaysian University English Test (MUET) and its Use for Placement Purposes: A Predictive Validity Study
}

\author{
Souba Rethinasamy \\ (rsouba@cls.unimas.my) \\ Universiti Malaysia Sarawak, Malaysia \\ Kee Man Chuah \\ (kmchuah@,cls.unimas.my) \\ Universiti Malaysia Sarawak, Malaysia
}

\begin{abstract}
The use of standardised English proficiency tests like IELTS and TOEFL for admission and placement purposes is widely practised in academic institutions throughout the world. Similarly in Malaysia, many tertiary institutions utilise the results of a localised version of such tests called the Malaysian University English Test (MUET) as a measure of students' proficiency level, prerequisite for admission, as well as placement in various academic programmes. This paper reports on the predictive validity of MUET as a measure of undergraduates' English language proficiency and the appropriacy of the MUET cut-off bands for placement purposes. The MUET bands of 2884 undergraduates from various faculties and the grade they obtained in an English language enhancement course were analysed to answer the research questions. The findings indicate a significant positive relationship between the undergraduates' MUET bands and their grades in the English language course. Chi square results also indicate that the difference between MUET band 3 undergraduates' ability to obtain good grades is significantly different compared to undergraduates with MUET bands 1 and 2. Besides providing evidence for MUET's validity as a measure of students' English language ability, the findings also recommend a need to review the cut-off MUET band for placement purposes.
\end{abstract}

\section{Introduction}

Globally, the vital role of the English language in tertiary institutions has long been recognised. Proficiency and competency in the language are regarded as a passport to better academic achievement (Bellingham, 1995; Cheng, 2008). With the increasing use of English in academic contexts, mastery of the language is now a must and no longer seen as a complementary competence particularly in the field of science and technology (Rea-Dickins \& Scott, 2007). Realising such importance, universities are taking various measures to assist students in improving their English language proficiency. One of those measures is offering a range of English language courses, some of which are compulsory for graduation requirements. Entry to such courses is often determined by the students' score in a proficiency test as predetermined by the university (Elder \& O'Loughlin, 2003) such as TOEFL (The Test of English as a Foreign Language), IELTS (International English Language Testing System) and ESOL exams (English for Speakers of Other Languages). Students with lower proficiency scores are usually required to enrol for remedial English 